\title{
Does Diachasmimorpha longicaudata (Hymenoptera: Braconidae) have a preferential instar to parasitize Tephritidae (Diptera)?
}

\author{
Roberta A. Rohr (10), Simone M. Jahnke (1) \& Luiza R. Redaelli (1)
}

Programa de Pós-Graduação em Biologia Animal, Instituto de Biociências, Universidade Federal do Rio Grande do Sul, Av. Bento Gonçalves, 9500 Prédio 43435, 91540-000 Porto Alegre, RS, Brazil. (robertarohr@gmail.com)

\author{
Received 26 November 2018 \\ Accepted 25 February 2019 \\ Published 28 March 2019 \\ DOI 10.1590/1678-4766e2019014
}

\begin{abstract}
Diachasmimorpha longicaudata (Ashmead, 1905) is a koinobiont parasitoid of Tephritidae larvae, the third instar larvae of which is considered preferential, but it is able to parasitize other larval stages and compete with native parasitoids. This study investigated the preference and parasitism capacity of $D$. longicaudata in larvae of different instar of Anastrepha fraterculus (Wiedemann, 1830) (AF) and Ceratitis capitata (Wiedemann, 1824) (CC). The experiments were carried out under laboratory conditions, one instar being offered at a time in parasitism units, with the following choices among the hosts: $25 \mathrm{AF}$ larvae and $25 \mathrm{CC}$ larvae (first, second and third instar were evaluated). The other test was a multiple-choice in relation to the instar, for larvae of the same host species, with three parasitism units being offered, with 15 larvae of each instar. The mean number of formed pupae, emerged parasitoids, parasitized pupae, unviable pupae and sex ratio were evaluated. In the first bioassay, the mean number of emerged parasitoids and parasitized pupae in the AF host were significantly higher in treatments with first and second instar larvae. For CC there was no difference between the instars tested. In the second bioassay, the mean value of emerged parasitoids and parasitized pupae, was higher in second and third instar larvae for CC, and for $\mathrm{AF}$ was in second instar larvae. The sex ratio was biased for males in all treatments in both bioassays. The results show that $D$. longicaudata can parasitize and be successful in all available larval instars, being able to compete with parasitoids of any instar.
\end{abstract}

KEYWORDS. Anastrepha fraterculus, Ceratitis capitata, exotic parasitoid, tephritids.

RESUMO. Diachasmimorpha longicaudata (Hymenoptera: Braconidae) tem um ínstar preferencial para parasitar Tephritidae (Diptera)? Diachasmimorpha longicaudata (Ashmead, 1905) é um parasitoide coinobionte de larvas de Tephritidae sendo que o terceiro ínstar larval é tido como o preferencial, mas pode parasitar outros estágios larvais e competir com os parasitoides nativos. Este estudo investigou a preferência e capacidade de parasitismo de D. longicaudata em larvas de diferentes ínstares de Anastrepha fraterculus (Wiedemann, 1830) (AF) e Ceratitis capitata (Wiedemann, 1824) (CC). Os experimentos foram realizados em condições laboratoriais, sendo oferecido um ínstar por vez em unidades de parasitismo, havendo escolha entre os hospedeiros: 25 larvas de AF e 25 larvas de CC (foram avaliadas larvas de primeiro, segundo e terceiro ínstar). O outro teste foi de múltipla escolha em relação ao ínstar, para larvas da mesma espécie hospedeira, sendo oferecidas três unidades de parasitismo, com 15 larvas de cada ínstar. Avaliou-se o número médio de pupários formados, parasitoides emergidos, pupários parasitados, pupas inviáveis e razão sexual. No primeiro bioensaio o número médio de parasitoides emergidos e pupários parasitados no hospedeiro AF foram significativamente superiores nos tratamentos com larvas de primeiro e segundo ínstar. Para CC não houve diferença entre os ínstares testados. No segundo bioensaio, o valor médio de parasitoides emergidos e de pupas parasitadas foi maior nas larvas de segundo e terceiro ínstar para CC, e para AF nas larvas de segundo ínstar. A razão sexual foi desviada para machos em todos os tratamentos, nos dois bioensaios. Os resultados demostram que $D$. longicaudata pode parasitar e ter sucesso em qualquer ínstar larval disponível, podendo competir com parasitoides de qualquer ínstar.

PALAVRAS-CHAVE. Anastrepha fraterculus, Ceratitis capitata, tefritídeos, parasitoide exótico.

Diachasmimorpha longicaudata (Ashmead, 1905) is a solitary, koinobiont, endoparasitoid from the Indo-Australian region, where it parasitizes at least 14 species of Bactrocera Macquart, 1835 (Diptera: Tephritidae) (WharTon \& GILSTRAP, 1983). It is widely used as a biological control agent worldwide for parasitizing species of tephritids (MonToYA et al., 2000; DeVESCOVI et al., 2017). It can be easily reared in laboratory conditions and it has a low specificity for hosts, being able to parasitize Ceratitis capitata (Wiedemann, 1824) and several species of Anastrepha Schiner, 1868 (Diptera: Tephritidae) (CARVAlHo \& Nascimento, 2002). It shows parasitism hability greater than $50 \%$ and can suppress up to $70 \%$ of the fruit fly populations innatural environment (Sivinski et al., 1996; Montoya et al., 2000).

Diachasmimorpha longicaudata usually parasitizes second and third instar of tephritids larvae (SIVINSKI et al., 2001; Sime et al., 2006), although there are records of preference for third instar and pupae (CARVALHO, 2005b; OvRUSKI et al., 2011; Montoya et al., 2017). Due to these specificities, the research groups that advocate this species release to biocontrol fruit flies argue that this parasitoid would not compete for oviposition sites with other species, especially the native braconid Doryctobracon areolatus (Szépligeti, 1911) (Hymenoptera: Braconidae), which has 
a preference for larvae in early stages of development (Matrangolo et al., 1998; Carvalho et al., 2000; Paranhos et al., 2013). Nevertheless, Murillo et al. (2015) verified that $D$. areolatus can also parasitize larvae of up to the third instar, which brings the niches of these species even closer. Diachasmimorpha longicaudata was imported from the United States of America in 1994 and introduced in Brazil by Embrapa Mandioca e Fruticultura Tropical, with the aim of studying its behavior and effectiveness to control fruit fly, aiming the implementation of a biological control program, started in Northeast Brazil (CARVALHO \& NASCimENTO, 2002). However, evaluations carried out a few years after their release showed that there were alterations in the presence of native parasitoid species and suggested the existence of interspecific competition in oviposition sites (CARVAlHo, 2005a). On the other hand, Meirelles et al. (2016), after release D. longicaudata in Rio Grande do Sul field, did not detect a negative impact on native parasitoid populations. Despite parasitizing preferentially third instar larvae (Montoya et al., 2018), we affirm that D. longicaudata is able of parasitizing and succeeding in any instar, differing from that generally described. The interaction between multiple species of parasitoids in the environment is not fully understood, and the release of $D$. longicaudata may be controversial. Thus, this work aimed to investigate the preference and parasitism capacity of $D$. longicaudata in larvae of native Anastrepha fraterculus (Wiedemann, 1830) and exotic $C$. capitata from different instars.

\section{MATERIAL AND METHODS}

Study site. The study was conducted at the Laboratory of Biology, Ecology and Biological Control of Insects (Bioecolab), at the Universidade Federal do Rio Grande do Sul, under controlled conditions of $26 \pm 1^{\circ} \mathrm{C}, 60 \pm 10 \%$ $\mathrm{RH}$, with 14 hours of photophase.

Host rearing. The adults of $A$. fraterculus and $C$. capitata were kept in wooden cages (45 x $30 \times 30 \mathrm{~cm})$, covered on the sides with voile fabric, receiving distilled water and a solid diet on an ad libitum basis, which consisted of crystal sugar, hydrolyzed protein, soybean extract $(3: 1: 1)$ and vitamin complex (Lavitan $-\mathrm{A}-\mathrm{Z}^{\circledR}$ ), in the ratio of two macerated tablets per $250 \mathrm{~g}$ of diet (adapted from JALDO et al., 2001). As an oviposition substrate for C. capitata, a 250 $\mathrm{ml}$ yellow plastic tube with small perforations (FAO/IAEA/ USDA, 2003) was used. For $A$. fraterculus, the substrate used was a blue tissue bag covered with silicone, as described in MeIRelLes et al. (2016). The eggs were collected daily and placed on polystyrene trays $(23.5 \times 18 \times 1 \mathrm{~cm})$, with an artificial diet based on organic carrot, beer yeast, corn flour, sugar, distilled water, sodium benzoate (Dinâmica ${ }^{\circledR}$ ), nipagin $\left(\right.$ Synth $\left.^{\circledR}\right)$ and citric acid $\left(\right.$ Synth $\left.^{\circledR}\right)$ (modified from TERÁN, 1977). After seven days, these were placed inside larger plastic trays $(51 \times 30 \times 9.5 \mathrm{~cm})$, with sterile sand and covered by organza, where they remained for approximately seven days for the pupation. Subsequently, the sand was sifted and the pupae obtained were placed in plastic containers (6.6 x 6.6 x $6 \mathrm{~cm}$ ) until emergence.

Parasitoids rearing. The rearing has started from the parasitized pupae of $A$. fraterculus, from Embrapa Clima Temperado, Pelotas, RS, Brazil. The adults were kept in wooden cages $(19.5 \times 16.5 \times 25.5 \mathrm{~cm})$, covered with organza material and fed with honey dissolved in water (7:3), offered in Petri dishes $(5 \times 5 \times 1.5 \mathrm{~cm})$ with cotton, water was provide by capillarity through a strip of Spontex Resist ${ }^{\mathbb{}}$ fabric. Third instar $C$. capitata larvae were placed in parasitism units, which consisted of a circular plastic plate ( $4 \mathrm{~cm}$ in diameter), with a $0.3 \mathrm{~cm}$ border, formed by a small layer of silicone, wrapped with white organza fabric stuck with a rubber band. After one hour of exposure, the larvae were returned to the artificial diet in polystyrene trays $(15.5 \times 15.5 \times 1 \mathrm{~cm})$ and stored in plastic trays $(41 \times 28 \times 7 \mathrm{~cm})$ on a layer of sand sterilized until the pupae formation. After five days, the sand was sifted, and the pupae were packaged in the same manner as for fly breeding, waiting for parasitoids emergence that were reintroduced to the breeding in new cages.

Parasitism in different instars between two host species. The females preference was evaluated by concomitantly offering 25 larvae of $A$. fraterculus (AF) and 25 larvae of $C$. capitata (CC) to five couples of parasitoids (eight days old). First, second and third instar larvae of the two host species were evaluated. The larvae were offered daily for five days, completing 60 replicates and totaling 1,500 larvae evaluated by treatment. The couples were kept in wooden cages $(15 \mathrm{x}$ $15.5 \times 20 \mathrm{~cm}$ ), covered with organza, offered water and food. The larvae were offered in parasitism units, consisting of a circular plastic plate $(2.7 \mathrm{~cm}$ in diameter), with a border of $0.2 \mathrm{~cm}$, formed by a small layer of silicone and encased in white voile, trapped with an elastic band, disposed on pots with $3.8 \mathrm{~cm}$ in height as support. The units were exposed for eight hours, and the larvae were then returned to the artificial diet in polystyrene trays and placed in plastic containers (35 x $17.5 \times 10 \mathrm{~cm}$ ) on a layer of sand until pupa formation.

In order to evaluate larval mortality without action of parasitoids (control treatment) 25 larvae of $A$. fraterculus and C. capitata (total of 50 larvae per cage) were placed in parasitism units and these remained in cages for eight hours without parasitoids presence. Following that, the larvae were kept in the same manner as described for breeding.

Multiple-choice parasitism test with different larval instars of the same host. The preference of $D$. longicaudata females was evaluated in cages as described previously with three parasitism units containing 15 larvae of first, second and third instar (total of 45 larvae per replicate) of one host species - AF or CC - to five couples of parasitoids (eight days old). The larvae were offered daily for five days, totalizing 30 replicates and 1,350 larvae evaluated. The units remained exposed for eight hours, and the larvae were then conditioned as described previously.

To evaluate larval mortality, without action of the parasitoids (control treatment), 15 instar larvae each, totalizing 45 larvae per cage, or $A$. fraterculus or $C$. capitata were placed in parasitism units and kep in the cages for the 
same time as described above, but without the presence of parasitoids.

For both bioassays, after five days, the sand was sifted and the pupae packed in plastic pots until the emergence of flies or parasitoids. The pupae of which there was no emergence were dissected for check the presence of parasitoids or flies. The mean numbers of formed pupae were recorded, as well as parasitized pupae (emerged parasitoids + pupae dissected with parasitoids), emerged parasitoids, unviable pupae [number of offered larvae - (number of flies emerged + emerged parasitoids)], sex ratio of parasitoids, and parasitism rate.

Statistical analysis. The mean values were analyzed for normality by the Shapiro-Wilk test and submitted to analysis of variance, the means being compared by ANOVA, followed by the Tukey test, with a significance level of 5\%.

The sex ratio (Rs) was estimated using the formula: $\mathrm{Rs}=$ number of females $/$ number of females + number of males. The Chi-square $\left(\chi^{2}\right)$ of heterogeneity was used to compare Rs between treatments. The parasitism index was calculated using the formula: IP = number of emerged parasitoids / number of pupae formed $\times 100$. The tests were performed using the BioEstat 5.0 software (AYRES et al., 2007).

\section{RESULTS}

\section{Multiple-choice parasitism in different instars between two host species}

Anastrepha fraterculus. The mean number of parasitized pupae and emerged parasitoids was significantly higher $(\mathrm{F}=30.5686$; $\mathrm{df}=2 ; \mathrm{p}<0.0001, \mathrm{~F}=35.4343$; df $=2 ; \mathrm{p}<0.0001$, respectively) in larvae of first and second instars when compared to third instar larvae (Fig. 1) (Tab. I). The parasitism rate was $73.8,74$ and $34 \%$ in first, second and third instar larvae, respectively.

The mean value ( $\pm \mathrm{SE}$ ) of pupae formed in control treatment (without presence of parasitoids) was $21.0 \pm$

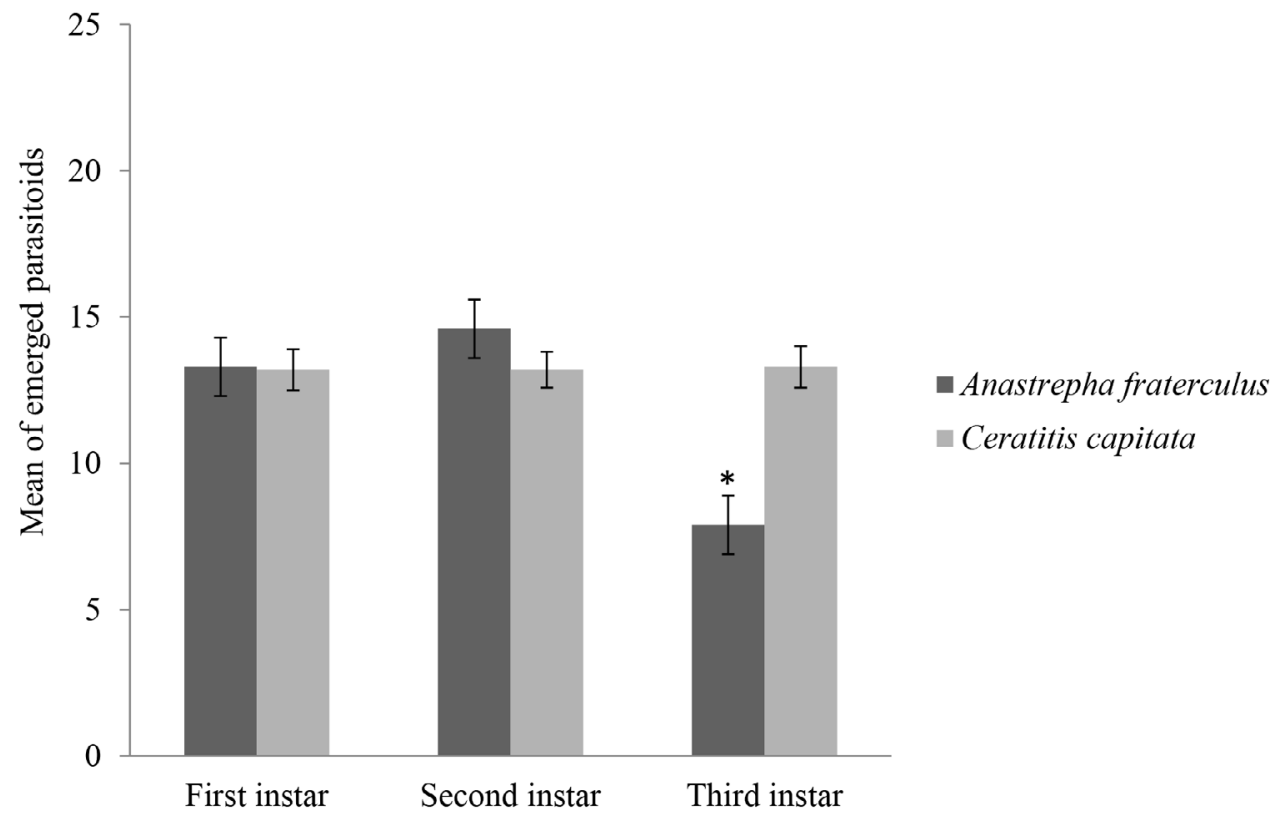

Fig. 1. Mean number of emerged parasitoids in hosts Anastrepha fraterculus (Wiedemann, 1830) and Ceratitis capitata (Wiedemann, 1824), exposed to parasitism by Diachasmimorpha longicaudata (AsHMEAD, 1905) on first, second and third-instar larvae. The bars correspond to the standard error. Bars with asterisk presented significant difference (ANOVA test, followed by the Tukey test, $\mathrm{p}<0.05$ ) of the other instars for the same host species.

Tab. I. Mean number ( \pm SE) of formed pupae, parasitized pupae, unviable pupae and sex ratio of hosts Anastrepha fraterculus (Wiedemann, 1830) and Ceratitis capitata (Wiedemann, 1824), exposed to parasitism by Diachasmimorpha longicaudata (Ashmead, 1905) on first, second and third-instar larvae. Lowercase letters compare the different treatments with the same host species. Upper case letters compare the same treatments against the two host species. ANOVA test, followed by Tukey $(\mathrm{p}<0.05)$. Sex ratio, tested by $\chi^{2}$ for heterogeneity. ${ }^{(1)}$ emerged parasitoids + pupae dissected with parasitoids; (2) number of larvae offered - (number of emerged flies + emerged parasitoids).

\begin{tabular}{|c|c|c|c|c|c|c|}
\hline \multirow{3}{*}{ Variables evaluated } & \multicolumn{6}{|c|}{ Instar } \\
\hline & \multicolumn{2}{|c|}{ First } & \multicolumn{2}{|c|}{ Second } & \multicolumn{2}{|c|}{ Third } \\
\hline & $\mathrm{AF}$ & $\mathrm{CC}$ & $\mathrm{AF}$ & $\mathrm{CC}$ & $\mathrm{AF}$ & $\mathrm{CC}$ \\
\hline Formed pupae & $17.9 \pm 0.80 \mathrm{bA}$ & $18.2 \pm 0.65 \mathrm{bA}$ & $19.6 \pm 0.44 \mathrm{abA}$ & $18.5 \pm 0.56 \mathrm{bA}$ & $21.4 \pm 0.78 \mathrm{aA}$ & $21.7 \pm 0.63 \mathrm{aA}$ \\
\hline Parasitized pupae ${ }^{(1)}$ & $13.3 \pm 0.68 \mathrm{aA}$ & $13.2 \pm 0.70 \mathrm{aA}$ & $14.6 \pm 0.60 \mathrm{aA}$ & $13.3 \pm 0.61 \mathrm{aA}$ & $7.9 \pm 0.65 \mathrm{bB}$ & $13.4 \pm 0.71 \mathrm{aA}$ \\
\hline Unviable pupae ${ }^{(2)}$ & $10.4 \pm 0.72 \mathrm{bA}$ & $9.2 \pm 0.66 \mathrm{aA}$ & $9.6 \pm 0.62 \mathrm{bA}$ & $10.5 \pm 0.58 \mathrm{aA}$ & $17.1 \pm 0.71 \mathrm{aA}$ & $9.4 \pm 0.70 \mathrm{aB}$ \\
\hline Sex ratio & $0.24 \mathrm{bA}$ & $0.10 \mathrm{bB}$ & $0.31 \mathrm{aA}$ & $0.21 \mathrm{aB}$ & $0.27 \mathrm{bA}$ & $0.10 \mathrm{bB}$ \\
\hline
\end{tabular}


0.79 (first instar), $18.6 \pm 2.10$ (second instar) and $23.2 \pm$ 1.05 (third instar) and they were not significantly different $(p>0.05)$ from those that had the presence of parasitoids. The mean number of pupae, when parasitoids were present, was higher in the third instar only when compared to the first $(F=6.1750 ; \mathrm{df}=2 ; \mathrm{p}=0.0030)$ (Tab. I). In the presence of parasitoids, the mean number of unviable pupae was higher when the third instar larvae were exposed $(\mathrm{F}=35.7765 ; \mathrm{df}=$ $2 ; \mathrm{p}<0.0001$ ), compared to the other two treatments (Tab. I). The mean $( \pm \mathrm{SE})$ of unviable pupae in the control was $6.0 \pm$ $1.05 ; 8.6 \pm 2.09$ and $4.8 \pm 1.42$, respectively, for the first, second and third instars, lower when compared to larvae of first and third instars that were exposed to parasitoids $(\mathrm{F}=5.6303 ; \mathrm{df}=1, \mathrm{p}=0.0194, \mathrm{~F}=44.3177, \mathrm{df}=1, \mathrm{p}<0.0001$, respectively).

The sex ratio of the offspring was higher in larvae that were exposed to parasitism in the second instar $\left(\chi^{2}=\right.$ $20.6 ; \mathrm{df}=5 ; \alpha=0.05)$. In all treatments, there were a higher number of males (Tab. I).

Ceratitis capitata. The mean number of parasitized pupae and emerged parasitoids was not significantly different between treatments ( $p>0.05)$ (Fig. 1) (Tab. I). The parasitism rate was $72.4 \%$ in first instar larvae and $71.3 \%$ and $71.1 \%$ in second and third instar larvae, respectively.

The mean value ( \pm SE) of pupae formed in the control was $19.8 \pm 2.01$ in the first instar, $21.2 \pm 0.55$ in the second instar and $21.7 \pm 0.63$ in the third instar, was not significantly different among treatments $(\mathrm{p}>0.05)$ from those that had the parasitoids presence. In the treatments with the parasitoids presence, the average pupae formed was higher in third instar larvae $(F=10.0897 ; d f=2 ; p=0.0002)$ (Tab. I). In the treatments with the presence of parasitoids, there was no difference between the instars in the mean number of unviable pupae $(\mathrm{p}>0.05)$ (Tab. I). In control, the mean numbers $( \pm \mathrm{SE})$ were $7.4 \pm 1.77 ; 7.4 \pm 1.44$ and $5.9 \pm 1.95$, respectively, for the first, second and third instars. There was no difference between treatments with parasitoids and their respective controls on larvae of the first and third instars $(p>0.05)$. The third instar had fewer unviable pupae in the control when compared to the treatment with parasitoids $(F=4.1045$; $\mathrm{df}=1 ; \mathrm{p}=0.0440)$.

The sex ratio of the offspring was higher in larvae exposed to parasitism in the second instar $\left(\chi^{2}=13.4 ; \mathrm{df}=5\right.$; $\alpha=0.05)$. In all treatments, there were a higher number of males (Tab. I).

Host preference. When comparing the same instar between the two host species, the mean number of parasitized pupae $(\mathrm{F}=32.9505 ; \mathrm{df}=1 ; \mathrm{p}<0.0001)(\mathrm{Tab} . \mathrm{I})$ and emerged parasitoids $(\mathrm{F}=38.7731 ; \mathrm{df}=1 ; \mathrm{p}<0.0001)$ was higher in C. capitata (CC) in the third instar (Fig. 1). Regarding the mean number of pupae formed, there was no difference between AF and CC in all treatments $(p>0.05)$. The mean number of unviable pupae was significantly higher only in the third instar of CC $(\mathrm{F}=59.1417$; $\mathrm{df}=1$; $\mathrm{p}<0.0001)$. The sex ratio was always higher in the host AF (Tab. I), regardless of the instar in which the larvae were exposed $\left(\chi^{2}=22.7 ; \mathrm{df}=2 ; \alpha=0.05-\right.$ first instar larvae; $\chi^{2}=23.0$; $\mathrm{df}=2 ; \alpha=0.05-$ second instar larvae, and $\chi^{2}=24.2$; $\mathrm{df}=2 ; \alpha=0.05-$ third instar larvae).

\section{Multiple-choice parasitism test with diferent larval instars of the same host}

Anastrepha fraterculus. The mean number of parasitized pupae and emerged parasitoids was significantly higher $(\mathrm{F}=9.3968 ; \mathrm{df}=2 ; \mathrm{p}=0.0004, \mathrm{~F}=9.3969 ; \mathrm{df}=2$; $\mathrm{p}=0.0004$, respectively) in second instar larvae (Tab. II). The parasitism rate was $66.9 \%, 86.9 \%$ and $60.3 \%$ in first, second and third instar larvae, respectively.

The mean value $( \pm \mathrm{SE})$ of pupae formed in the control was $13.2 \pm 0.86 ; 14.0 \pm 0.31$ and $14.8 \pm 0.20$ for first, second and third instar larvae, respectively. The control was not significantly different from the others treatments with parasitoids presence $(\mathrm{p}>0.05)$. There was also no difference in the mean of puparia formed between the instars

Tab. II. Mean number ( \pm SE) of formed pupae, parasitized pupae, emerged parasitoids, unviable pupae and sex ratio of hosts Anastrepha fraterculus (Wiedemann, 1830) and Ceratitis capitata (Wiedemann, 1824) exposed to parasitism by Diachasmimorpha longicaudata (Ashmead, 1905) on first, second and third-instar larvae. Lowercase letters compare the different treatments with the same host species. ANOVA test, followed by Tukey ( $<<0.05)$. Sex ratio, tested by $\chi^{2}$ for heterogeneity. ${ }^{(1)}$ emerged parasitoids + pupae dissected with parasitoids; ${ }^{(2)}$ number of larvae offered $-($ number of emerged flies + emerged parasitoids).

\begin{tabular}{|c|c|c|c|}
\hline \multirow{3}{*}{ Variables evaluated } & \multicolumn{3}{|c|}{ Anastrepha fraterculus } \\
\hline & \multicolumn{3}{|c|}{ Instar } \\
\hline & First & Second & Third \\
\hline Formed pupae & $11.4 \pm 0.46 \mathrm{a}$ & $12.2 \pm 0.57 \mathrm{a}$ & $12.1 \pm 0.86 \mathrm{a}$ \\
\hline Parasitized pupae ${ }^{(1)}$ & $7.6 \pm 0.64 b$ & $10.6 \pm 0.55 \mathrm{a}$ & $7.3 \pm 0.59 b$ \\
\hline Emerged pupae & $7.6 \pm 0.64 b$ & $10.6 \pm 0.55 \mathrm{a}$ & $7.3 \pm 0.59 b$ \\
\hline Unviable pupae ${ }^{(2)}$ & $5.2 \pm 0.58 b$ & $4.3 \pm 0.54 \mathrm{~b}$ & $7.7 \pm 0.57 \mathrm{a}$ \\
\hline \multirow[t]{2}{*}{ Sex ratio } & $0.27 \mathrm{~b}$ & $0.32 \mathrm{~b}$ & $0.70 \mathrm{a}$ \\
\hline & \multicolumn{3}{|c|}{ Ceratitis capitata } \\
\hline Formed pupae & $10.2 \pm 0.50 \mathrm{~b}$ & $13.9 \pm 0.27 \mathrm{a}$ & $14.3 \pm 0.15 \mathrm{a}$ \\
\hline Parasitized pupae ${ }^{(1)}$ & $8.0 \pm 0.54 b$ & $11.9 \pm 0.43 \mathrm{a}$ & $11.4 \pm 0.57 \mathrm{a}$ \\
\hline Emerged pupae & $8.0 \pm 0.54 b$ & $11.9 \pm 0.43 \mathrm{a}$ & $11.4 \pm 0.57 \mathrm{a}$ \\
\hline Unviable pupae ${ }^{(2)}$ & $5.7 \pm 0.50 \mathrm{a}$ & $2.9 \pm 0.45 \mathrm{c}$ & $3.6 \pm 0.57 \mathrm{~b}$ \\
\hline Sex ratio & $0.41 \mathrm{~b}$ & $0.45 \mathrm{~b}$ & $0.61 \mathrm{a}$ \\
\hline
\end{tabular}


with the presence of parasitoids $(p>0.05)$ (Tab. II). In the treatments with parasitoids, the mean number of unviable pupae was higher in those exposed in the third instar $(\mathrm{F}=$ 9.4386; $\mathrm{df}=2 ; \mathrm{p}=0.0004$ ) (Tab. II). In the control, the mean value $( \pm \mathrm{SE})$ were of $2.6 \pm 0.67 ; 2.0 \pm 0.83$ and $0.6 \pm 0.4$ for the first, second and third instars, respectively, being lower than treatments with parasitoids only in the third instar (F $=23.2425 ; \mathrm{df}=1 ; \mathrm{p}=0.0001$ ).

The sex ratio of offspring generated was higher in third instar larvae, with more females emerged $\left(\chi^{2}=47.9\right.$; $\mathrm{df}=5 ; \alpha=0.05)($ Tab. II).

Ceratitis capitata. The mean number of parasitized pupae and emerged parasitoids $(\mathrm{F}=16.6636 ; \mathrm{df}=2 ; \mathrm{p}<$ $0.0001 ; \mathrm{F}=16.36637 ; \mathrm{df}=2 ; \mathrm{p}<0.0001$, respectively) was higher in the second and third instars (Tab. II). The parasitism rate was $78.2 \%$ for first instar larvae and $85.9 \%$ and $79.9 \%$ for second and third instar larvae, respectively.

The mean values $( \pm \mathrm{SE})$ of pupae formed in the control was $12.6 \pm 0.74 ; 14.8 \pm 0.20$ and $14.6 \pm 0.24$ for first, second and third instar larvae, respectively. There was no difference between control and treatments parasitoids presence $(p>$ $0.05)$. In the treatments with parasitoids, the second and third instars were the ones with the highest mean number of pupae formed ( $\mathrm{F}=41.3569 ; \mathrm{df}=2 ; \mathrm{p}<0.0001)$ (Tab. II). The mean number of unviable pupae in tests with parasitoids presence was higher in first instar larvae $(\mathrm{F}=8.2180 ; \mathrm{df}=$ $2 ; p=0.0008)($ Tab. II). The control had the mean values $( \pm \mathrm{SE})$ of $2.4 \pm 0.74 ; 0.2 \pm 0.2$ and $0.4 \pm 0.24$ for the first, second and third instars, respectively. All treatments that had the presence of parasitoids had a higher mean number of unviable pupae, when compared to their controls $(\mathrm{F}=$ $6.7424 ; \mathrm{df}=1 ; \mathrm{p}=0.0134$ for first, $\mathrm{F}=5.6186 ; \mathrm{df}=1 ; \mathrm{p}=$ 0.0224 for second, and $\mathrm{F}=5.0216 ; \mathrm{df}=1 ; \mathrm{p}=0.0301$ for third instar).

The sex ratio of offspring generated was higher in larvae exposed in the third instar, with more females emerged $\left(\chi^{2}=64.4 ; \mathrm{df}=5 ; \alpha=0.05\right)($ Tab. II $)$.

\section{DISCUSSION}

The lack of difference in pupae number formed between treatments, even with the presence of parasitoids, is expected, considering that $D$. longicaudata is a koinobiont parasitoid (OvRUSKI et al., 2000), that does not kill the larvae of its hosts immediately, allowing them to finish their development and pupate before causing death. This is known for Braconidae fruit fly parasitoids that emerge only at the pupal stage (OvRUSKI et al., 2000; 2003). The higher mortality in some treatments, when compared to the control in this experiment, may be due to the stress caused to the larvae by parasitism, test punctures or even by superparasitism (OvRUSKI et al., 2011; HARBI et al., 2018). In our study, when only one instar was offered, $D$. longicaudata efficiently parasitized larvae of both the first and second instars of $A$. fraterculus, showing that their response may be conditioned to the environment, differing from other studies that registered their preference for the late larval stages (Ovruski et al., 2011; VAN NieUwenhove \& OvRUSKI,
2011; Montoya et al., 2017). In addition, D. longicaudata showed no instar preference in C. capitata larvae when exposed only one at a time. On the other hand, when the three instars were offered concomitantly, the highest parasitism was in the second and third instar. In general, parasitoids usualy to have a preferential or single instar to parasitize, as seek to specialize in relation to the species they use as hosts and can be specialize in certain stages thereof (MatTIACCI \& Dike, 1995; Montoya et al., 2018). In the case of $D$. longicaudata, there are records that it is able to parasitize the second and third instars (SIVINSKi et al., 2001; Sime et al., 2006). Additionally, this species has been shown a broad plasticity, adapting easily to environmental conditions (CARVALHO \& NASCimento, 2002).

When the three larval instars of $A$. fraterculus were exposed simultaneously, the second instar was preferred, differing from the studies that suggested the third as preferential (OvRUSKi et al., 2011; VAN NieUWENHOVE \& OvRUSKI, 2011; Montoya et al., 2017). The interaction between $D$. longicaudata and $A$. fraterculus can be considered as a "new association", as they do not share an intense history of coevolution, a factor that may influence the parasitoid-host relationship (HoKKANEN \& PIMENTEL, 1989), and even change the parasitoid's preferences for the parasite. The fact that $A$. fraterculus larvae are larger than C. capitata (MeIRELLES et al., 2013; OliveIra et al., 2014; SÁ et al., 2018) or those of many Bactrocera species (MAU \& Kessing, 1992; THOMAS et al., 2001; SINGH et al., 2010), their original hosts, may cause the $D$. longicaudata to parasitize also the first instars of the South American fruit fly, recognizing the youngest larvae as appropriate for their development, with sufficient nutritional quality and quantity to meet their needs, opposing previous studies (LóPEZ et al., 2009; HARVEY et al., 2012).

In the environment, hosts can be found at different stages and densities inside the fruits, which may reflect parasitoid choices (NúÑEZ-CAMPERO et al., 2016). Thus, there is no ensure that $D$. longicaudata will not compete for the same oviposition niche of the native parasitoids. For parasitoids, a single host comprises its entire source of larval food and can have great influence on the adult's fitness. In general, larger hosts have more qualitative resources to supply parasitoid fitness (MatTiaCCI \& Dicke, 1995; OvRUSKI et al., 2011; HARVEY et al., 2012). This apparently did not influence in D. longicaudata choice in our study, being effective even in first and second instar larvae. In this case, possibly even smaller larvae can guarantee the quantity and nutritional quality for $D$. longicaudata development, as their hosts were originally species of Bractocera (WHARTON \& GILSTRAP, 1983), smaller than those tested in this study (Singh \& RamamurThy, 2010).

The sex ratio of $D$. longicaudata offspring grown in both $A$. fraterculus and $C$. capitata was biased for males, indicating that host or environmental conditions may not have been propper for the parasitoid (GODFRAY, 1994). When different instars of the same host species were offered simultaneously, a larger number of females emerged in second and third instar larvae, respectively. The data found in our study corroborate the records that Tephritidae parasitoids 
that parasitize larvae in later stages tend to produce a larger number of females (EBEN et al., 2000; OvRUSKi et al., 2011; VAN NieUwenhove \& OvRUSKI, 2011). On the other hand, MonToYa et al. $(2011,2012)$ argue that larval size influences superparasitism, which, in turn, influences the sexual ratio of $D$. longicaudata. When moderate superparasitism occurs (2-6 scars per pupa), there is a trend of female emergence, with no detrimental effects on the demographic parameter to offspring, including longevity and fecundity (GONZÁLEZ et al., 2007; MONTOYA et al., 2011; 2012). It is possible that this occurred in our study on the second bioassay, although we did not record the number of scars left on the larvae, given that it could help to evaluate superparasitism and corroborate this hypothesis.

When the hosts $A$. fraterculus and C. capitata were exposed simultaneously, we observed that in $A$. fraterculus there was a higher proportion of females. In relation to the emergence of parasitoids and mortality, however, both had similar means, except for third instar larvae of $A$. fraterculus, with a higher mean number of unviable pupae and lower number of emerged parasitoids. Although $C$. capitata has been used for a long time in rearing of $D$. longicaudata in several places of the world, A. fraterculus has already been used, showing a good performance as a host (Messing et al., 1993; Van Nieuwenhove \& Ovruski, 2011, Meirelles $e t$ al., 2016; HARBI et al., 2018), and our study confirms this data. This aspect is important in mass rearing since studies such as those by Segura et al. (2007) and Tognon et al. (2013) have demonstrated that parasitoids that are reared in a given host are easier to recognize through chemical tracks, obtained by memory or learning, which would provide greater efficiency in the control of the target pest (MatTiaCCI \& DiCKe, 1995; EBEn et al., 2000).

Our study demonstrates the plasticity of $D$. longicaudata at the moment of host selection, and that it can be considered a good competitor. It is important that $D$. longicaudata coexist with other parasitoids, not leading their populations to decline. Therefore, before releasing exotic wasps species, it is important to know how they respond (behavior) in the field. Other factors such as biotic and abiotic conditions (SIVINSKI et al., 2000), chemical tracks of plants (EITAM et al., 2003; SiLVA et al., 2007; SEgURA et al., 2016) and patch isolation (EITAM et al., 2004) may also interfere in search and parasitism. Considering that not all environments have abiotic and biotic barriers, which may help in the niches division, and that $D$. longicaudata is a competitive species, easily parasitizing any instar, its introduction into new environments should be well evaluated, so as not to cause suppression of other species and a subsequent imbalance in the environment.

Acknowledgments. We thank the Coordenação de Aperfeiçoamento de Pessoal de Nivel Superior (CAPES) from Brazil for providing a scholarship to Roberta A. Rohr and the Conselho Nacional de Desenvolvimento Cientifico e Tecnológico $(\mathrm{CNPq})$ for the fellowships were awarded to the second (Proc. \# 306435/2015-2) and third authors (Proc. \# 308113/2016-0). We would also like to thank to Dr. Dori Edson Nava and Dr. Rafael Gonçalves from Embrapa Clima Temperado, for providing the pupae with parasitoids.

\section{REFERENCES}

Ayres, M.; Ayres Jr., M.; Ayres, D. L. \& Santos, A. S. 2007. BioEstat 5.0. Aplicações Estatísticas nas Áreas de Ciências Biológicas e Médicas. Belém, Sociedade Civil de Mamirauá, MCT, Imprensa Oficial do Estado do Pará. xii +324 p.

CARvalho, R. S. 2005a. Avaliações das liberações inoculativas do parasitoide exótico Diachasmimorpha longicaudata (Ashmead) (Hymenoptera: Braconidae) em pomar diversificado em Conceição Almeida, BA. Neotropical Entomology 34(5):799-805.

Carvalho, R. S. 2005b. Diapause in fruit fly parasitoids in the recôncavo baiano, Brazil. Neotropical Entomology 34(4):613-618.

Carvalho, R. S. \& Nascimento, A. S. 2002. Criação de Diachasmimorpha longicaudata para controle biológico de moscas-das-frutas (Tephritidae). In: Parra, J. R. P.; Botelho, P. S. M.; CorrêA-Ferreira, B. S. \& Bento, J. M. S. Controle biológico no Brasil: Parasitoides e Predadores. Ribeirão Preto, Holos, p. 165-179.

Carvalho, R. S.; Nascimento, A. S. \& Matrangolo, W. J. R. 2000. 14. Controle Biológico. In: Malavasi, A. \& Zucchi, R. A. Moscas-dasfrutas de importância econômica no Brasil: conhecimento básico aplicado. Ribeirão Preto, Holos, p. 113-117.

Devescovi, F.; Bachmann, G. E.; Nussenbaum, A. L.; Viscarret, M. M.; Cladera, J. L. \& Segura, D. F. 2017. Effects of superparasitism on immature and adult stages of Diachasmimorpha longicaudata Ashmead (Hymenoptera: Braconidae) reared on Ceratitis capitata Wiedemann (Diptera: Tephritidae). Bulletin of Entomological Research 107:756-767.

Eben, A.; Benrey, B.; Sivinski, J. \& Aluja, M. 2000. Host species and host plant effects on preference and performance of Diachasmimorpha longicaudata (Hymenoptera: Braconidae). Environmental Entomology 29(1):87-94.

Eitam, A.; Holler, T.; Sivinski, J. \& Aluja, M. 2003. Use of fruit chemical cues for laboratory rearing of Doryctobracon areolatus (Hymenoptera: Braconidae), a parasitoid of Anastrepha spp. (Diptera: Tephritidae). Florida Entomologist 86(2):211-216.

Eitam, A.; Sivinski, J.; Holler, T. \& Aluja, M. 2004. Biogeography of braconid parasitoids of the Caribbean fruit fly (Diptera: Tephritidae) in Florida. Annals of the Entomological Society of America 97(5):928939.

FAO/IAEA/USDA. 2003. Manual for Product Quality Control and Shipping Procedures for Sterile Mass-Reared Tephritid Fruit Flies, Version 5.0. Vienna, International Atomic Energy Agency, 85p. Available at $<$ http://www-naweb.iaea.org/nafa/ipc/public/ipc-massreared-tephritid.html $>$. Accessed on October 2018.

Godfray, H. C. J. 1994. Parasitoids: behavioral and evolutionary ecology. In: Krebs, J. R. \& Clutton-Brock, T. Monographs in Behavior and Ecology. Princeton, Princeton University Press, p. 483.

González, P. I.; Montoya, P.; Perez-Lachaud, G.; Cancino, J. \& Liedo, P. 2007. Superparasitism in mass reared Diachasmimorpha longicaudata (Ashmead) (Hymenoptera: Braconidae), a parasitoid of fruit flies (Diptera: Tephritidae). Biological Control 40:320-326.

Harbi, A.; Beitia, F.; Ferrara, F.; Chermiti, B. \& Sabater-Muñoz, B. 2018. Functional response of Diachasmimorpha longicaudata (Ashmead) over Ceratitis capitata (Wiedemann): Influence of temperature, fruit location and host density. Crop Protection 109:115-122.

Harvey, J. A.; Gols, R.; Vet, L. E. M. \& Kruidhof, H. M. 2012. Development of a hyperparasitoid wasp in different stages of its primary parasitoid and secondary herbivore hosts. Journal of Insect Physiology 58:1463-1468.

Hokkanen, H. M. T. \& Pimentel, D. 1989. New association in biological control: theory and practice. The Canadian Entomologist 121(10):829840 .

Jaldo, H. E.; Gramajo, M. C. \& Willink, E. 2001. Mass rearing of Anastrepha fraterculus (Diptera: Tephritidae): a preliminary strategy. Florida Entomologist 84:716-718.

López, O. P.; Hénaut, Y.; Cancino, J.; Lambin, M.; Cruz-López, L. \& RoJAs, J. C. 2009. Is host size an indicator of quality in the mass-reared parasitoid Diachasmimorpha longicaudata (Hymenoptera:Braconidae)? Florida Entomologist 92(3):441-449.

Matrangolo, W. J. R.; Nascimento, A. S.; Carvalho, R. S.; Melo, E. D. \& De Jesus, M. 1998. Parasitoides de moscas-das-frutas (Diptera: 
Tephritidae) associados a fruteiras tropicais. Anais da Sociedade Entomológica do Brasil 27(4):593-603.

Mattiacci, L. \& Dicke, M. 1995. The parasitoid Cotesia glomerata (Hymenoptera: Braconidae) discriminates between first and fifth farval instars of its host Pieris brassicae, on the basis of contact cues from frass, silk, and herbivore-damaged leaf tissue. Journal of Insect Behavior 8(4):485-498.

Mau, R. \& Kessing, J. 1992. “Ceratitis capitata (Weidmann)”. Available at $<\mathrm{http}$ :/www.extento.hawaii.edu/kbase/crop/Type/ceratiti.htm $>$. Accessed on October 2018.

Meirelles, R. N.; Redaelli, L. R. \& Ourique, C. B. 2013. Comparative biology of Diachasmimorpha longicaudata (Hymenoptera: Braconidae) reared on Anastrepha fraterculus and Ceratitis capitata (Diptera: Tephritidae). Florida Entomologist 96(2):412-418.

Meirelles, R. N.; Redaelli, L. R.; Jahnke, S. M.; Ourique, C. B. \& OzóRIO, D. B. 2016. Parasitism of fruit flies (Tephritidae) in field, after the releases of Diachasmimorpha longicaudata (Ashmead) (Hymenoptera: Braconidae) in Rio Grande do Sul. Revista Brasileira de Fruticultura 38 (2):e-673.

Messing, R. H.; Klungness, L. M.; Purcell, M. \& Wong, T. Y. 1993. Quality control parameters of mass-reared Opiine parasitoids used in augmentative biological controlo of Tephritid fruit flies in Hawaii. Biological Control 3:140-147.

Montoya, P.; Cacino, J.; Pérez-Lachaud, G. \& Liedo, P. 2011. Host size, superparasitism and sex ratio in mass-reared Diachasmimorpha longicaudata, a fruit fly parasitoid. Biological Control 56:11-17.

Montoya, P.; GÁlvez, C. \& DíAz-Fleischer, F. 2018. Host availability affects the interaction between pupal parasitoid Coptera haywardi (Hymenoptera: Diiapridae) and larval-pupal parasitoid Diachasmimorpha longicaudata (Hymenoptera: Braconidae). Bulletin of Entomological Research 12:1-9.

Montoya, P.; Liedo, P.; Benrey, B.; Cancino, J.; Barrera, J. F.; SivinSKi, J. \& Aluja, M. 2000. Biological Control of Anastrepha spp. (Diptera: Tephritidae) in mango orchards through augmentative releases of Diachasmimorpha longicaudata (Ashmead) (Hymenoptera: Braconidae). Biological Control 18:216-224.

Montoya, P.; López, P.; Cruz, J.; López, F.; Cadena, C.; Cancino, J. \& LIEDO, P. 2017. Effect of Diachasmimorpha longicaudata releases on the native parasitoid guild attacking Anastrepha spp. larvae in disturbed zones of Chiapas, Mexico. BioControl 62:581-593.

Montoya, P.; Pérez-Lachaud, G. \& Liedo P. 2012. Superparasitismin the fruit fly parasitoid Diachasmimorpha longicaudata (Hymenoptera: Braconidae) and the implications for mass rearing and Augmentative release. Insects 3:900-911.

Murillo, F. D.; Cabrera-Mireles, H.; Barrera, J. F.; Liedo, P. \& Montoya, P. 2015. Doryctobracon areolatus (Hymenoptera, Braconidae) a parasitoid of early developmental stages of Anastrepha obliqua (Diptera, Tephritidae). Journal of Hymenoptera Research 46:91-105.

NúÑez-CAmpero, S. R.; BeniteZ-VIeyra, A.; Gorla, D. E. \& Ovruski, S. M. 2016. Changes in Diachasmimorpha longicaudata (Hymenoptera: Braconidae) functional response as a consequence of host density choice. Annals of the Entomological Society of America 109(5):730-736.

Oliveira, P. C. do C.; Fonseca, E. D.; Alvarenga, C. D.; Giustolin, T. A.; Rabelo, M. M. \& Coutinho, C. R. 2014. Efeito da idade das larvas de Ceratitis capitata (Wied.) sobre a qualidade biológica do parasitoide Diachasmimorpha longicaudata (Ashmead). Arquivos do Instituto Biológico 81(3):244-249.

OvRuski, S. M.; ALUJA, M.; SivinSKI, J. \& WhaRTon, R. 2000. Hymenopteran parasitoids on fruit-infesting Tephritidae (Diptera) in Latin America and the southern United States: Diversity, distribution, taxonomic status and their use in fruit fly biological control. Integrated Pest Management Reviews 5:81-107.

Ovruski, S. M.; Bezdjian, L. P.; Van Nieuwenhove, G. A.; AlbornozMedina, P. \& Schliserman, P. 2011. Host preference by Diachasmimorpha longicaudata (Hymenoptera: Braconidae) reared on larvae of Anastrepha fraterculus and Ceratitis capitata (Diptera: Tephritidae). Florida Entomologist 94(2): 195-200.
Ovruski, S. M.; Colin, C.; Soria, A.; Oroño, L. E. \& Schliserman, P. 2003. Introducción y producción en laboratorio de Diachasmimorpha tryoni y Diachasmimorpha longicaudata (Hymenoptera: Braconidae) para el control biológico de Ceratitis capitata (Diptera: Tephritidae) en la Argentina. Revista de la Sociedad Entomológica Argentina 62(3-4):49-59.

Paranhos, B. J.; Sivinski, J.; Stuhl, C.; Holler, T. \& Aluja, M. 2013. Intrinsic competition and competitor-free-space influence the coexistence of parasitoids (Hymenoptera: Braconidae: Opiinae) of Neotropical Tephritidae (Diptera). Environmental Entomology 42(4):717-723.

Sá, L. P.; Alvarenga, C. D.; dos Santos, Z. C.; Souza, M. D. C.; Da Cruz, G.; Camargos, M. G. \& Giustolin, T. A. 2018. Parasitism of Diachasmimorpha longicaudata (Ashmead) on two fruit fly species. Arquivos do Instituto Biológico 85:e172017.

Segura, D. F.; Nussenbaum, A. L.; Viscarret, M. M.; Devescovi, F.; Bachmann, G. E.; Corley, J. C.; Ovruski, S. M. \& Cladera, J. L. 2016. Innate host habitat preference in the parasitoid Diachasmimorpha longicaudata: functional significance and modifications through learning. PLoS ONE 11(3):1-18.

Segura, D. F.; Viscarret, M. M.; Paladino, L. Z. C.; Ovruski, S. M. \& CladerA, J. L. 2007. Role of visual information and learning in habitat selection by a generalist parasitoid foraging for concealed hosts. Animal Behaviour 74:131-142.

SiLVA, J. W. P.; Bento, J. M. S. \& ZuCChI, R. A. 2007. Olfactory response of three parasitoid species (Hymenoptera: Braconidae) to volatiles of guavas infested or not with fruit fly larvae (Diptera: Tephritidae). Biological Control 41:304-311.

Sime, K. R.; DaAne, K. M.; NAdel, H.; FunK, C. S.; Messing, H.; ANDrews JR, J. W.; Johnson, M. W. \& PicketT, C. H. 2006. Diachasmimorpha longicaudata and D. kraussii (Hymenoptera: Braconidae), potential parasitoids of the olive fruit fly. Biocontrol Science and Technology 16(2):169-179.

Singh, S. K.; Kumar, D. \& Ramamurthy, V. V. 2010. Biology of Bactrocera (Zeugodacus) tau (Walker) (Diptera: Tephritidae). Entomological Research 40:259-263

Sivinski, J. M.; Calkins, C. O.; Baranowski, R. M.; Harris, D.; Brambila, J; Diaz, J.; Burns, R. E.; Holler, T. \& Dodson, G. 1996. Suppression of caribbean fruit fly (Anastrepha suspensa (Loew) Diptera: Tephritidae) population through releases of the parasitoid Diachasmimorpha longicaudata (Ashmead) (Hymenoptera: Braconidae). Biological Control 6:177-185.

Sivinski, J.; PIÑERo, J. \& AluJA, M. 2000. The distributions of parasitoids (Hymenoptera) of Anastrepha fruit flies (Diptera: Tephritidae) along an altitudinal gradient in Veracruz, Mexico. Biological Control 18:258269.

SivinSKI, J.; Vulinec, K. \& AluJA, M. 2001. Ovipositor length in a guild of parasitoids (Hymenoptera: Braconidae) attacking Anastrepha spp. fruit flies (Diptera: Tephritidae) in southern Mexico. Annals of the Entomological Society of America 94(6):886-895.

TERÁN, H. R. 1977. Comportamiento alimentario y su correlación con la reproducción en hembras de Ceratitis capitata (Wied.) (Diptera: Tephritidae). Revista Agronomica del Nordeste Argentino 14:17-34.

Thomas, M.; Heppner, J.; Woodruff, R.; Weems, H. \& Steck, G. 2001. "Featured Creatures". Available at $<$ http://entnemdept.ufl.edu/ creatures/fruit/mediterranean_fruit_fly.htm $>$. Accessed on October 2018.

TOGNON, R.; SANT'ANA, J. \& JAHNKE, S. M. 2013. Aprendizagem e memória de Telenomus podisi (Hymenoptera, Platygastridae). Iheringia, Série Zoologia 103(3):266-271.

VAN Nieuwenhove, G. A. \& OvRuski, S. M. 2011. Influence of Anastrepha fraterculus (Diptera: Tephritidae) larval instars on the production of Diachasmimorpha longicaudata (Hymneoptera: Braconidae) progeny and their sex ratio. Florida Entomologist 94(4):863-868.

Wharton, R. A. \& Gilstrap, F. E. 1983. Key to and status of Opiinae Braconid (Hymenoptera) parasitoids used in biological control of Ceratitis and Dacus S. L. (Diptera: Tephritidae). Annals of The Entomological Society of America 76:721-742. 